\title{
KONDISI OLAHRAGA TRADISIONAL MENYIPET DAN BALOGO DI KOTA PALANGKA RAYA
}

\author{
The Condition of Menyipet And Balogo Traditional Sports In Palangka Raya City
}

\author{
Abdul Rahman Azahari ${ }^{1}$ \\ ${ }^{1}$ Universitas Palangkaraya
}

\begin{abstract}
Abstrak
Adanya globalisasi mengakibatkan perubahan budaya termasuk melunturnya olahraga tradisional. Teori yang digunakan pada penelitian ini yaitu konsep budaya, konsep pendidikan jasmani, serta konsep olahraga menyipet dan balogo. Analisa dengan metode penelitian kualitatif dan diharapkan mendapatkan hasil yang mendalam (insight) sekaligus menyeluruh (holistic). Sebagaimana menyipet, dahulu kala diperuntukkan sebagai kegiatan berburu dengan alat sipet. Sekarang menyipet dan balogo digunakan sebagai lomba budaya olahraga tradisional. Pemerintah Kota Palangka Raya berupaya melestarikan kebudayaan olahraga menyipet dan balogo dengan cara festival menyipet, festival balogo, invitasi menyipet dan balogo, kurikulum menyipet dan balogo serta pengembangan menyipet dan balogo. Masih terbuka lebar peluang untuk meneliti masalah fenomena kondisi olahraga tradisional menyipet dan balogo di Palangka Raya.
\end{abstract}

Kata Kunci: Olahraga Tradisional; Menyipet; Balogo

\section{Abstract}

The strengthening of globalization in Indonesia that brings new patterns of life and entertainment inevitably has a certain impact on the social and cultural life of the Indonesian people, including various kinds of traditional sporting activities. The theory used in this study is the concept of culture, the concept of physical education, and the sport of menyipet and balogo concept. Research use qualitative method and expected to get deep results (insight) as well as comprehensive (holistic). Like menyipet, it used to be a hunting activity to add a variety of side dishes to be consumed, besides sipet as well as a tool to defend yourself. But now, hunting is prohibited, then sipet is developed into a traditional sports arena along with balogo. As a cultural wealth in the form of traditional sports that are loaded with various noble teachings and values, the city government of Palangka Raya strives to preserve and revive the sport of menyipet and balogo through various festivals and incorporate it into the local content curriculum in high schools. The opportunity is still wide open to examine the problem of the phenomenon of traditional menyipet and balogo sports conditions in Palangka Raya.

Keywords: Traditional Sports; Menyipet; Balogo

\section{A. PENDAHULUAN}

Salah satu corak budaya bangsa yang saat ini telah meredup dan hampir hilang adalah olahraga daerah. Acara olahraga tradisional yang sudah jarang dimainkan dalam upacara-upacara adat, penyambutan tamu, dan hiburan oleh masyarakat primitive Indonesia dan suku-suku yang ada di seluruh Indonesia. Olahraga tradisional menjadi sebuah daya tarik pariwisata dan tentunya menjadi sebuah kekhasan sebuah daerah/bangsa. Kekhasan tersebut merupakan jati diri suatu daerah/bangsa yang membedakan Negara satu dengan Negara yang lainnya.

Olahraga tradisional yang ada di Indonesia merupakan indikator dari kekayaan budaya nusantara dan sebagai pertanda dari kebhinekaan Indonesia. Namun demikian tidak hanya sesederhana itu, sebab olahraga tradisional juga memiliki muatan-muatan luhur yang sangat bermanfaat untuk pertumbuhan, perkembangan, kepribadian bangsa Indonesia. Olahraga tradisional tidak bisa dipisahkan dengan masyarakat Indonesia, khususnya masyarakat di Indonesia yang tinggal di pedesaan. Karena olahraga daerah bagian dari adat masyarakat, tumbuh dan berkembang sesuai dengan lingkungan olahraga tersebut lahir atau berada. Namun dalam realitanya, olahraga tradisional menglami kemunduran. Hal ini lebih disebabkan oleh adanya pengaruh kemajuan ilmu pengetahuan. 
Pemerintah menganggap olahraga sebagai hal yang penting untuk meningkatkan kesehatan masyarakat. Melalui olahraga tradisional diharapkan tubuh menjadi bugar dan juga memiliki moral yang sehat (Ora et Labora). Oleh karena itu sudah waktunya pemerintah juga lebih memperhatikan masalah olahraga ini pada olahraga terkini dan olahraga daerah tradisional.

Olahraga tradisional dipandang bermanfaat, karena memiliki unsur-unsur yang positif dalam mengembangkan potensi manusia terutama generasi muda. Generasi muda sangat memerlukan ketangkasan, kecepatan, ketepatan, kecermatan, kekuatan, kelenturan, kejujuran, kerjasama yang selanjutnya generasi muda menjadi bugar, sehat lahir dan batinnya, mengingat generasi muda sebagai generasi harapan bangsa.

Menyikapi fenomena kegiatan olahraga daerah di Kota Palangka Raya sebagaimana dijelaskan di atas, muncul beberapa pertanyaan mendasar, yaitu: (1) mengapa olahraga daerah mulai punah? , (2) apakah majunya budaya suatu masyarakat harus meninggalkan budayanya sendiri ? padahal budayanya sendiri tersebut sebagai warisan leluhur, (3) faktor apa yang mendorong sampai terjadi demikian ?, (4) terus siapa yang harus bertanggung jawab, (5) bagaimana dengan pemerintah, apakah pemerintah membiarkan hal tersebut terjadi ?. Sebab itu yang perlu dibahas dalam penelitian ini yakni: (a) bagaimana acara dan keadaan menyipet dan balogo di Kota Palangka Raya? (b) Apa saja faktor penghambat pengembangan kegiatan menyipet dan balogo di Kota Palangka Raya?

\section{B. LANDASAN TEORITIS}

\subsection{Tinjauan Tentang Kebudayaan}

Mengetahui kebiasaan social harus mengetahui kebudayaan sekitarnya. Tak satupun masyarakat lepas dari kebudayaan. Selo Soemardjan dan Soelaeman Soemardi Dalam Seokanto S, (1999) merumuskan kebudayaan sebagai semua hasil karya, rasa, dan cipta masyarakat. Karya menghasilkan benda untuk dimanfaatkan kehidupan sehari-hari masyarakat.

\subsection{Pemberdayaan Olahraga dan Kesejahteraan Sosial}

Ada pertanda, seperti dalam laporan Direktur Pemberdayaan IPTEK Olahraga (Rusli Luthan dkk, Oktober 2001), berdasarkan kasus penyelenggaraan penataran di dua provinsi, dalam rangka mempertahankan budaya menyipet dan balogo masing-masing Kalimantan Tengah dan Sumatera Barat, para pengelola dan Pembina olahraga pada umumnya lemah dalam memahami fenomena olahraga dari perspektif yang luas, kurang tajam dalam perencanaan dan ketiadaan fokus, di samping parameter keberhasilan pembinaan selalu dikaitkan dengan rangking daerah

Dalam PON, seperti dalam PON XV 2000 yang lalu. Ada ungkapan yakni daerah merasa malu karena rengkingnya merosot. Sementara itu, faktor yang rill dalam kehidupan seperti tipis renggangnnya penduduk, keterbukaan masyarakat, dan struktur ekonomi kurang diperhitungkan dalam perencanaan. Kelemahan memang dijumpai dalam hal human capital, berupa ketiadaan tenaga ahli dan pembina baik dari segi jumlah maupun kapasitas membangun lebih-lebih dalam hal sosial capital, berupa ketiadaan jaringan (link) kerjasama. Bahkan ada tanda-tanda tentang lemahnya kerjasama antar lembaga terkait, yang menyebabkan daerah semakin kurang berdaya dalam mengatasi masalah, sehingga ke depan, pembinaan institusi dan nilai-nilai kolateral kebersamaan itu harus menjadi sebuah prioritas. Karena itu, dalam lapangan tersebut dikemukakan, secara nasional, kita tidak memiliki landasan yang memadai untuk membangun sistem pembinaan kuat, lebihlebih untuk tujuan olahraga prestasi.

Belajar dari pengalaman tersebut di atas, maka sesungguhnya selama ini, pihak pemerintah telah mencoba untuk menempatkan pelajaran olahraga sesuai dengan tempatnya, dalam rangka ikut menjawab tantangan zaman. Tema yang ditampilkan di balik kebijakan publik itu di tanah air kita adalah olahraga untuk integrasi sosial dan nasionalisme di samping prestasi olahraga sebagai simbol prestise dalam rangka menegakkan postur bangsa di tingkat internasional.

Berkaitan dengan konsep tersebut maka pembangunan olahraga yang dimaksud adalah sebuah kesisteman yang bersifat holistik - bukan semata-mata olahraga elit-kompetitif-yang menempatkan pendidikan jasmani sebagai sebuah "gound floor" untuk memupuk aspirasi berolahraga dan kebiasaan aktif di sepanjang hayat, dan diatas dasar itu, terbangun sub-sistem olahraga rekreasi yang bersifat meluas, dan olahraga kompetitif yang bersifat elit. Kata kunci yang berkaitan dengan partisipasi masyarakat dalam sub-sub sistem itu adalah motivasi para pelaku olah raga itu sendiri.

\subsection{Lomba Menyipet dan Balogo}

\subsubsection{Lomba Menyipet (Sifat: Lomba)}

a. Maksud dan Tujuan Lomba

b. Kriteria Peserta dan Kegiatan 
1. Peserta adalah utusan pemerintahan dari Kalimantan Tengah.

2. Pemerintah Kabupaten/Kota dapat mengirimkan maksimal 2 (dua) regu yaitu satu regu putra dan satu regu putri.

3. Satu kelompok terdiri dari tiga orang.

4. Sipet (sumpit) terbuat dari bahan kayu, anak sumpit (damek) terbuat dari bambu atau dari bahan kayu. Pelimping dari bahan kertas atau palawi, disediakan oleh peserta daerah masing-masing.

5. Peserta lomba menggunakan pakaian khas daerah masing-masing dan bagi tim yang tidak menggunakan pakaian khas daerah didiskualifikasi.

6. Perlombaan menggunakan sistem gugur.

7. Tempo perlombaan/pertandingan dengan $5 \times$ rambahan; $1 \times$ rambahan $=10$ (sepuluh) anak sumpit.

8. Sasaran menyumpit ke atas dan mendatar (bawah).

9. Jarak menyumpit untuk peserta putra 20 $\mathrm{m}$, dan jarak menyumpit peserta putri 15 $\mathrm{m}$.

10. Cara menyumpit bias bebas asal tidak melewati garis start.

11. Bidikan pada bentuk binatang.

12. Dinilai berdasarkan hasil bidikan.

13. Jika ada anak sumpit yang mengenai sasaran antar nilai, yang diambil nilai tertinggi.

14. Pelanggaran yang timbul akibat rendahnya tingkat pengendalian diri, sportivitas dan lain-lain yang mencemarkan dari pada diselenggarakannya permainan ini diancam dikurangi nilai hingga dinyatakan diskualifikasi.

\subsubsection{Lomba Balogo (Sifat: Lomba)}

a. Maksud dan Tujuan Lomba

Menumbuhkan kepedulian upaya melestarikan nilai-nilai tradisi warisan masa lampau, berupa permainan Balugu dimainkan dengan menggunkan teknik dan strategi yang tinggi dan menjunjung tinggi sportivitas. Memberikan tontonan yang bernuansa hiburan.

b. Kriteria Peserta dan Kegiatan

1. Pengikut lomba merupakan perwakilan dari Kalimantan Tengah.

2. Dimainkan beregu/menggunakan sistem gugur.

3. Pemerintah Kab/Kota dapat mengirimkan maksimal 2 (dua) regu yaitu satu regu putra dan satu regu putri.

4. Satu regu beranggotakan 5 (lima) orang, 3 (tiga) orang pemain dan 2 (dua) orang cadangan dan tipeng (tongkat/stik) disediakan oleh peserta.

5. Peserta menggunakan kostum olahraga/tradisional masyarakat dayak.

6. Ukuran lugu: panjang $9 \mathrm{~cm}$, dan lebar 8 $\mathrm{cm}$.

7. Lugu disiapkan oleh panitia.

8. Jarak lugu I-II-III $8 \mathrm{~m}$.

9. Waktu 30 menit,(15menit $x 2$ babak)

10. Dimainkan di atas lapangan beraspal/tanah disesuaikan.

\section{METODE PENELITIAN}

Metode yang digunakan dalam penelitian ini adalah kualitatif dan diharapkan mendapatkan hasil yang mendalam (insight) sekaligus menyeluruh (holistic). Penentuan informan, berperan penting dan menentukan terhadap keberhasilan penelitian. Memperhatikan kenyataan sosial dan realita bahwa peneliti adalah dosen olahraga dan Rekreasi, dan aspek lain bahwa peneliti juga orang asli Kalimantan Tengah yang dari kecil sampai sekarang dibesarkan di Kalteng, dan sekaligus sebagai pelaku olahraga tradisional tersebut. Maka penentuan informan yang sesuai dengan metodologi dan pendekatan kualitatif adalah purposive (Sanggar Kanto dalam Burhan Bungin, 2003: 51). yaitu penentuan informan dengan pertimbangan-pertimbangan tertentu (sesuai dengan metodologis). Adapun pertimbangan dimaksud antara lain, pengambil kebijakan (Dinas Budaya dan Pariwisata), dan (Guru Olahraga).

Selanjutnya, bilamana dalam proses pengumpulan data sudah tidak lagi ditemukan variasi informasi, maka peneliti tidak perlu lagi untuk mencari informan baru, karena proses pengumpulan informasi dianggap sudah selesai. Pada penelitian metode kualitatif tidak dipersoalkan jumlah sampel. Jumlah sampel sangat dipengaruhi kesesuaian sumber wawancara dengan kompleksitas serta variasi fenomena sosial yang diteliti. Namun jika informasi yang dikumpulkan sudah jenuh, maka dilakukan penghentian pengumpulan data.

Alat untuk mengumpulkan data menjawab permasalahan penelitian ini adalah menggunakan instrumen pendekatan kualitatif sebagai berikut: (a) Alat utama adalah seorang peneliti sendiri sebagai alat berfikir analisis mampu membuat/menarik kesimpulan/verifikasi terhadap fenomena yang diteliti; (b) Instrumen bantu adalah teridiri dari sarana-sarana atau alat-alat yang dapat membantu si peneliti (instrumen utama) dalam menarik kesimpulan atau membuat verifikasi terhadap fenomena yang diteliti. 
Dalam hal ini peneliti akan terjun langsung ke lapangan untuk mengamati, melakukan wawancara mendalam, dan melakukan pengecekan data yang dibutuhkan. Cara menampung data dalam penelitian sebagai berikut: Observasi bias ada dua, yaitu berpartisipasi dan tidak berpartisipasi. Pada pengamatan tanpa peran serta, pengamat hanya melakukan satu fungsi, yaitu mengadakan pengamatan. Pengamatan berpartisipasi yaitu penulis sebagai pengamat sekaligus anggota kelompok yang diamati. (Moleong, 1991;126-127). Dalam penelitian ini pengamatan dilakukan pada setiap ada kegiatan yang menyajikan tentang olahraga daerah di Kota Palangka Raya.

Sebagaimana ditegaskan Lincoln dan Guba (Moleong, 1991,135) maksud mengadakan Tanya jawab atau wawancara yaitu: merekam suatu kegiatan, perasaan dan motivasi; merekonstruksi kebulatan-kebulatan demikian sebagai yang dialami masa lalu, memproyeksikan kebulatan-kebulatan sebagai yang telah diharapkan untuk dialami pada masa yang akan datang; mencocokkan, mengubah, dan memperluas informasi yang diperoleh dari orang lain, baik manusia maupun bukan manusia (triangulasi); dan mencocokkan, mengubah dan memperluas konstruksi yang dikembangkan oleh peneliti sebagai pengecekan anggota. Dengan mengacu kepada fokus penelitian, wawancara akan dilakukan terhadap informan kunci yang terdiri dari pengambil keputusan dan kebijakan kaitannya dengan budaya dan olahraga tradisional (Disbudpar), guru pendidikan jasmani dan Olahraga, tokoh masyarakat.

Arikunto $(1997 ; 107)$ menjelaskan bahwa untuk mempermudah identifikasi sumber data penelitian dapat disingkat 3P, yaitu Person (sumber data berupa orang), Place (sumber data tempat), dan Paper (sumber data berupa simbol).

\section{PEMBAHASAN}

\subsection{Keadaan Olahraga Menyipet dan Balogo di Masyarakat Kota Palangka Raya}

Untuk membahas keadaan olahraga tradisional menyipet dan balogo di masyarakat Kota Palangka Raya terdapat festival dan upaya pelestarian yang meliputi :
a. Festival menyipet
b. Festival balogo
c. Invitasi menyipet dan balogo
d. Kurikulum menyipet dan balogo
e. Pengembangan menyipet dan balogo Festival yang berkaitan dengan budaya di Palangka Raya dikenal dengan Festival Budaya Isen Mulang (FBIM). Festival ini dilaksanakan setahun sekali bertepatan dengan hari ulang tahun provinsi Kalimantan Tengah yaitu pada setiap tanggal 19-24 bulan Mei. Adapun yang difestivalkan adalah aneka ragam kesenian dan budaya masyarakat Kalimantan Tengah, maupun masyarakat pendatang namun bermukim atau penduduk kota Palangka Raya, seperti suku Jawa (Jawa Tengah, Jawa Timur, Jawa Barat). Adapun acara di festival ini dimulai dari acara pembukaan yaitu diisi acara pawai yang diikuti ribuan orang dari berbagai kabupaten kota di provinsi Kalimantan Tengah, Lomba membuat makanan tradisional, lomba tari, permainan tradisional dan juga pemilihan putra/putri pariwisata.

Apa yang dipelajari dan dilatihkan ataupun di invitasikan baik itu seni, olahraga tradisional, kuliner lokal, atau kuliner khas Dayak, budaya, model yang ditandai dengan pemilihan putri wisata (putra maupun putri), pokoknya segala seni budaya tradisional ditampilkan dan dilombakan. Hanya kekurangannya hal ini kurang didukung oleh berbagai fasilitas atau sarana prasarana yang memadai. Memang di Palangka Raya sebagai ibukota provinsi Kalimantan belum memiliki gedung kesenian yang cukup representatif, gedung olahraga yang proporsional, arena dayung yang cukup representatif. Ini mengakibatkan budaya Isen Mulang tidak berjalan secara maksimal.

\subsubsection{Festival Menyipet}

Dulu menyipet bukan jenis olahraga, namun menyipet sebagai salah satu jenis pekerjaan yang bertujuan untuk menambah variasi jenis lauk atau sekaligus untuk membasmi hama tanaman (berburu babi). Menyipet merupakan salah satu senjata bagi orang Dayak, disamping untuk melindungi diri dari serangan musuh juga sebagai senjata untuk berburu. Oleh karena itu setiap anak laki-laki maupun perempuan sangat tertarik dan diajari oleh orang tuanya dan khususnya bagi anak laki-laki selalu diajak oleh orang tuanya untuk berburu dengan alat sipet. Bahkan senjata sipet ini sangat ditakuti oleh orang-orang Belanda pada era penjajahan Belanda dulu, karena penggunaan sipet tidak menimbulkan suara, tetapi jika terkena sudah bisa dipastikan akan mati. Hal ini dapat terjadi karena diujung sipet telah dibubuhi racun yang mematikan.

Zaman sudah berubah, masyarakat yang terdidik cukup banyak, dan mereka selalu memilih mencari yang sesuai atau setingkat dengan latar belakang pendidikannya. Ini berarti mereka tidak lagi kembali ke desa untuk berburu babi atau rusa, melainkan mengembangkan dan mewujudkan apa yang menjadi idealismenya dalam pekerjaan. Hal yang demikian wajar saja 
sebab pendidikan merupakan salah satu agen perubahan sosial.

Sementara itu luas hutan juga semakin berkurang, sehingga peluang untuk berburu binatang juga semakin menipis, sehingga secara perlahan mulai terjadi pergeseran, yang dulu sipet merupakan senjata untuk berburu atau mempertahankan diri, namun karena banyak masyarakat yang bekerja di kantoran, maka sipet dari orang tua mereka dipajang menjadi souvenir atau hiasan di rumah-rumah, sebagai simbol keturunan atau kepahlawanan dari leluhur mereka.

Disisi yang lain pengaruh kemajuan teknologi semakin membawa kemajuan,dan secara perlahan berpengaruh pada sikap atau perilaku masyarakat dan dalam cakupan yang lebih luas juga berpengaruh pada nilai-nilai budaya yang ada di masyarakat. Akibatnya nilainilai budaya terkikis, bergeser dan bisa jadi berubah dari asalnya dan bangga pada nilai-nilai budaya asing. Hal inilah yang selalu menjadi kekhawatiran orang tua maupun tokoh-tokoh masyarakat.

Masyarakat Dayak ingin melanjutkan pendidikan yang lebih tinggi, bukan tanpa tujuan, hal seperti ini sebagaimana tindakan dari Parsons bahwa setiap orang melakukan sesuatu sudah tentu memiliki tujuan, baik vertikal maupun harizontal. Kemudian mereka memilih pekerjaan, menentukan masa depannya sendiri merupakan kebesan setiap orang untuk memilih. Kebebasan memilih, kebebasan bertindak sesuai dengan keinginannya. Festival menyipet dan balogo digunakan pemerintah untuk menjaga olahraga daerah.

\subsubsection{Festival Balogo}

Olahraga balogo merupakan jenis permainan anak-anak tempo dulu sebagai pengisi waktu sehabis panen padi atau pada acara-acara adat, namun sekarang permainan seperti itu anak-anak sudah tidak mau lagi melakukan, mereka lebih asyik main permainan elektronik (game di computer). Sebagai permainan team, maka unsur kerja sama, kerja keras, taat sama wasit, sangsi atau hukuman dari wasit jika melanggar, semangat sportivitas, dari para pemain dan wasit serta official merupakan norma yang harus dipatuhi.

Permainan balogo merupakan suatu permainan yang sangat menghormati dan mematuhi apa yang telah disepakati bersama. Jadi sebelum permainan balogo dimulai, team dari masing-masing regu, bersama dengan wasit, official berunding mengenai berbagai aturan yang harus dipatuhi bersama. Jadi pada permainan balogo sangat menjunjung tinggi azaz musyawarah mufakat. Pada permainan balogo sarat dengan berbagai ajaran kebaikan antara lain ajjaran kerjasama, ajaran kejujuran, ajaran tentang menyelesaikan masalah dengan musyawarah mufakat dan ajaran kejujuran. Karena dalam kehidupan bersama dalam masyarakat tidak menutup kemungkinan nilai-nilai budaya tersebut tadi sangat diperlukan, agar kehidupan bermasyarakat menjadi harmonis. Atas alasan itulah maka pemerintah sangat mendukung permainan ini untuk dilestarikan. Hal itulah yang menjadi salah satu dari tujuan festival balogo dilaksanakan.

Sebagaimana pada menyipet, festival balogopun juga mempunyai tujuan yang ingin dicapai. Disamping bertujuan agar balogo menjadi tetap eksis (para remaja juga menyenagi hal ini), juga pada permainan ini secara tidak langsung terjadi proses penanaman nilai-nilai budaya sebagaimana tersebut diatas pada para pemainnya, sehingga para pemain balogo tertanam jiwa kejujuran, sikap tidak egois, sikap kerjasama, sikap kerja keras dan musyawarah mufakat dalam menyelesaikan persoalan.

\subsubsection{Invitasi Menyipet dan Balogo}

Invitasi untuk olahraga tradisional menyipet dan balogo di kota Palangka Raya diadakan setiap tahun sekali menjelang hari ulang tahun kota Palangka Raya. Dalam kesempatan ini pemerintaha kota Palangka Raya sekaligus juga mencari bibit unggul yang akan mewakili pemerintahan kota dalam festival budaya yang diselenggarakan di pemerintahan provinsi Kalimantan Tengah pada bulan Mei setiap tahunnya juga dalam rangkaian ulang tahun atau hari jadi provinsi Kalimntan Tegah. Oleh karena itu semua club menyipet yang ada di kota Palangka Raya sudah mempersiapkan diri untuk melakukan latihan dalam rangka meningkatkan ketrampilan mereka baik menyipet maupun balogo.

\subsubsection{Kurikulum Menyipet dan Balogo}

Disdikpora mempunyai tanggung jawab sesuai dengan amanat Undang undang Nomor 3 Tahun 2005, tentang Keolahragaan Nasional, bahwa olahraga tradisional yang ada harus tetap dilestarikan. Hal ini menambah wawasan murid SMA dan SMK tentang olahraga daerah.

\subsubsection{Pengembangan Menyipet dan Balogo}

Pemerintah memasukkan olahraga daerah menyipet dan balogo ke dalam Kurikulum muatan local SMA dan SMK sehingga sudah seharusnya hal tersebut menjadi sesuatu yang rutin dipelajari oleh siswa, namun tidak demikian faktanya. Pemerintah kurang menyediakan peralatan menyipet dan balogo. 
Artinya, kebijakan pengadaan olahraga menyipet dan baloo dari pemrintah tidak didukung penyediaan sarana dan prasarana. Akibatnya pelaksanaan olahraga tradisional menyipet dan balogo di sekolah tidak berjalan sebagaimana mestinya. Artinya upaya pelestarian dan pengembangan melalui sekolah kurang berhasil. Invitasi menyipet dan balogo dilakukan selalu berkaitan dengan hari ulang tahun suatu instansi, belum disusun secara organisatoris dan sistematis sebagaimana layaknya organisasi olahraga. Namun invitasi dan festival yang dilakukan sebagai upaya pengembangan dari olahraga tradisional tersebut dengan harapan nantinya bisa dilaksanakan suatu even internasional. Sebagaimana yang terjadi pada pertunjukan Isen Mulang yang memang menamplkan berbagai acara seni, ketrampilan dan berbagai budaya masa lalu, dan juaranya nantinya akan diikutkan pada Internasional Borneo Sipet Tournament (BOST) di Kalimantan Barat.

Secara konsep langkah-langkah pengembangan olahraga tradisonal menyipet dan balogo sudah cukup baik, mulai dari memasukan olahraga tradisional menyipet dan balogo kedalam kurikulum, kemudian melakukan invitasi, dari invitasi berlanjut ke festival, juara di festival akan mewakili provinsi dan bertanding di tingkat antar provinsi, yaitu Internasional Borneo Sipet Tournament (BOST), namun demikian pesertanya sudah termasuk Malaysia, Brunei dan Philipina. Berangkat dari BOST kemudian mengikuti di kejuaraan tingkat ASEAN Tourism Forum (ATF).

\subsection{Kendala Melestarikan Olahraga Menyipet} dan Balogo

Faktor kendala melestarikan olahraga menyipet dan balogo dikelompokkan menjadi dua, yaitu faktor internal dan faktor eksternal.

\subsubsection{Kendala Internal}

\subsubsection{Monoton}

Pada olahraga menyipet dan balogo kurang adanya perkembangan cara bermain dari jaman dahulu. Hal ini kurang menarik bagi generasi sekarang dalam bermain menyipet dan balogo. Generasi sekarang lebih menyukai permainan game modrn lewat gadget.

\subsubsection{Tingkat Kesulitan yang Tinggi}

Kesulitan menyipet cukup tinggi. Diperlukan latihan yang intensif. Hal ini dikarenakan harus cukup latihan meniup, ketepatan sasaran damek dan latihan memegang sipet yang berat.

\subsubsection{Kendala Faktor Eksternal}

Faktor yang menjadi kendala eksternal diperlukan sosialisasi pada masyarakat serta mengadakan festival secara rutin.

\subsubsection{Kurangnya Koordinasi antar Instansi}

Diperlukan kerjasama untuk melestarikan menyipet dan balogo. Namun koordinasi antara Dinas Pariwisata, Sekolah dan club olahraga masih kurang. Selain itu, pendanaan lomba menyipet dan balogo masih digabungkan dengan anggaran di Festival Isen Mulang.

\subsubsection{Lemahnya Kedudukan Mata Pelajaran Olahraga Tradisonal dalam Kurikulum sekolah (Muatan Lokal)}

Untuk melestarikan olahraga tradisional menyipet dan balogo, Dinas pendidikan memasukkannya dalam kurikulum. Namun dukungan dana pada sekolah yang menyelenggarakan belum ada, diklat untuk guru olahraga juga belm ada, ditambah lagi saling menyalahkan antar lembaga jika terjadi kekurangan. Ketertarikan guru olahraga sendiri pada olahraga menyipet dan balogo juga belum maksimal dikarenakan olahraga ini belum dijadikan bahan ujian nasional.

\subsubsection{Keterbatasan Sarana/Prasarana latihan}

Proses belajar olahraga tradisional menyipet dan balogo akan berhasil jika ditunjang dengan sarana dan prasarana. Dengan sarana dan prasarana yang cukup ini memudahkan siswa untuk konsentrasi latihan. Kualitas kemajuan mempelajari olahraga menyipet dan balogo juga ditentukan oleh jumlah sarana dan prasarana yang memenuhi dengan jumlah siswa untuk latihan yang efektif dan efisien.

\subsection{Pendidikan Budaya dalam Olahraga Menyipet dan Balogo}

Sudah diketahui bersama bahwa olahraga dapat menjadi media dalam membangun karakter seseorang. Olahraga dan aktivitas fisik adalah salah satu cara bagi seseorang untuk meningkatkan kebugaran serta mengoptimalisasikan fungsi organ-organ tubuh. Namun demikian, selain untuk tujuan di atas olahraga serta aktivitas fisik dapat pula dijadikan sarana bagi seseorang maupun sekelompok orang untuk membangun karakter masing-masing. Seperti diketahui bahwa dengan berolahraga, karakter individu dapat dengan mudah diketahui serta dapat membawa seseorang ke dalam situasi yang lebih baik.

\subsubsection{Sikap Sportivitas}


Karakter dan sportivitas itu sulit untuk didefinisikan secara pasti, sehingga terdapat beberapa pendapat dan definisi. Seseorang yang berkarakter memiliki kebijaksanaan untuk mengetahui dan membedakan mana yang benar dan mana yang salah, jujur, dapat dipercaya, adil, hormat, dan bertanggung jawab, mengakui dan belajar dari kesalahan, dan berkomitmen untuk hidup menurut prinsip-prinsip tersebut (Dimyati, 2010). Terkait dengan hal tersebut di atas, penulis dapat merangkum definisi tersebut menjadi sebuah pengertian sederhana mengenai karakter, yaitu sebuah cara untuk bersikap secara terhormat kepada seluruh komponen pertandingan. Dalam hal ini seluruh komponen pertandingan meliputi pelatih, lawan, wasit, penonton, dan lain sebagainya terkait dengan pertandingan tersebut.

Sportifitas yaitu merupakan kata sifat yang berarti jujur dan kesatria atau gagah. Dan kata sportifitas yang sebagai kata benda mempunyai arti orang yang melakukan olahraga tersebut (harus) memiliki kejujuran dan sikap ksatria dalam bertindak dan berperilaku saat berolahraga, seperti disiplin, mengikuti ketentuan dan peraturan yang telah ditetapkan atau yang telah disepakati bersama, terutama saat mengikuti suatu pertandiang atau perlombaan olahraga. Jadi sportifitas dalam olahraga adalah perilaku atau tindakan dari seorang atau sekelompok olahragawan yang memperlihatkan sikap jujur, kesatria, disiplin, dan menaati ketentuan dan peraturan pertandingan/ perlombaan olahraga. Untuk mencapai sesuatu yang diharapkan.

\subsubsection{Sikap Ksatria}

Kesatria (sering juga ditulis ksatria atau satria) adalah kasta atau warna dalam agama Hindu. Kasta ksatria merupakan bangsawan dan tokoh masyarakat yang bertugas sebagai penegak keamanan, penegak keadilan, pemimpin masyarakat, pembela kaum tertindas atau kaum lemah karena ketidakadilan dan ketidakbenaran. Tugas utama seorang kesatria adalah menegakkan kebenaran, bertanggung jawab, lugas, cekatan, pelopor, memperhatikan keselamatan dan keamanan, adil, dan selalu siap berkorban untuk tegaknya kebenaran dan keadilan. Pada zaman dahulu, ksatria merujuk pada kasta bangsawan, tentara, hingga raja.

Pada zaman sekarang, kesatria merujuk pada profesi seseorang yang mengabdi pada penegakan hukum, kebenaran dan keadilan prajurit, bisa pula berarti perwira yang gagah berani atau pemberani. Kelompok ini termasuk pemimpin negara, pimpinan lembaga atau tokoh masyarakat yang tugasnya untuk menjamin terciptanya kebenaran, kebaikan, keadilan, dan keamanan masyarakat, bangsa, dan negara.
Adapun yang dimaksud dengan bersikap ksatria dalam olahraga adalah berjiwa kesatria yaitu sikap dimana kita berbuat sesuatu yang menghasilkan kebaikan antara kita dan orang lain. Dalam makna yang sesungguhnya adalah "mengalah" karena lebih mengutamakan kepentingan orang lain daripada kepentingan diri sendiri, hal itulah yang kini sulit untuk dicapai. Mengalah bukan berarti kalah, namun berbuat sesuatu yang membuat situasi yang lebih terkendali. Biarlah diri kita tersakiti, namun yakinlah suatu saat rasa sakit itu akan terobati dan tergantikan dengan kebahagiaan.

\section{B. E. KESIMPULAN DAN REKOMENDASI}

\subsection{Kesimpulan}

Olahraga daerah menyipet dan balogo merupakan sebagian dari kekayaan budaya masyarakat Dayak di Palangka Raya yang sering diikutsertakan pada Festival Budaya Isen Mulang di Provinsi Kalimantan Tengah. Sebagai kekayaan budaya yang berupa olahraga tradisional yang sarat dengan berbagai ajaran dan nilai-nilai luhur jadi pemerintah berupaya melestarikan dengan memasukkan pada pelajaran olahraga dan festival kebudayaan Isen Mulang. Hanya sayangnya upaya pemerintah kota tersebut tidak didukung dengan dukungan dana, kelengkapan fasilitas dan sarana/prasarana, kegiatan pendidikan dan latihan bagi guru, kurangnya invitasi, sehingga upaya tersebut menjadi setengah hati. Olahraga daerah menyipet dan balogo hanya ada pada acara perayaan ulang tahun kota Palangka Raya dan Festival Budaya Isen Mulang saja. Para pemain atau atlit dari olahraga tersebut rata-rata sudah dewasa (minimal 30 tahun ke atas), sehingga secara perlahan olahraga tersebut akan musnah seirama dengan semakin tuanya para pemainnya.

\subsection{Saran}

Sehubungan dengan apa yang telah disimpulkan sebagai hasil dari penelitian ini, maka dapat disarankan bahwa :

1. Bagi Pemerintah

Dalam upaya melestarikan olahraga tradisional tidak cukup hanya mengikut sertakan dalam acara perayaan ulang tahun kota Palangka Raya dan memasukan ke dalam materi/ jenis pelajaran di sekolah saja, namun hendaknya disertai dengan dukungan dana, fasilitas dan sarana/prasarana serta kegiatan invitasi-invitasi di antara club-club yang ada. Oleh karena itu pada Dinas Pendidikan disarankan untuk mengadakan kegiatan Pekan Olahraga Tradisional Pelajar dengan perlombaan menyipet dan balogo. Disamping itu hendaknya anttar instansi melakukan koordinasi dalam upaya pembinaan. 
Disarankan kepada pemerintah yang terkait dengan olahraga tradisional untuk mematenkan hak cipta menyipet dan balogo tersebut menjadi milik dan budaya masyarakat Dayak.

2. Bagi Generasi Muda

Kepada generasi muda disarankan hendaknya harus bisa menghargai dan menjunjung tinggi warisan budaya leluhur melalui aktivitas oleharaga tradisional tersebut. Oleh karena itu kepada generasi muda maupun siswa Sekolah Menengah Atas hendaknya rajin berlatih olahraga tradisional tersebut, sehingga olahraga tradisional tersebut bisa tetap lestari dan berkembang. Mau siapa lagi kalau tidak para generasi muda yang melestarikan dan mengeembangkannya.

\section{Bagi Masyarakat}

Kepada masyarakat kota Palangka Raya dapat disarankan bahwa hendaknya masyarakat dapat mendukung apa yang menjadi kebijakan pemerinttah dan lembaga pendidikan, yaitu memiliki sikap peduli dan merasa ikut memiliki dan tanggung jawab untuk mengembangkan menyipet dan balogo. Sebab olahraga tradisional sebagai warisan budaya leluhur wajib untuk dilestarikan dan dikembangkan, walaupun hal ini tidak mudah.

\section{F. REFERENSI}

Arikunto, Suharsimi (1997). Prosedur Penelitian: Suatu Pendekatan dan Praktek. Jakarta Rineka Cipta.

Bungin, Burhan. 2003. Analisis Data Penelitian Kualitatif, PT. RajaGrafindo Persada, Jakarta.
Dimyati. (2010). Peran Guru sebagai Model Dalam Pembelajaran Karakter dan Kebajikan Moral Melalui Pendidikan Jasmani. Yogyakarta: Cakrawala Pendidikan, 85-98Krober, A.L., C. Kluckhohn, 1952, Culture, Critical Review of Consepts and Definitions, Cambrige, Peabody Museum of American Anthropology.

Koentjaraningrat, 1990. Pengantar Ilmu Antropologi, Rineka Cipta, Jakarta.

Moleong, Lexy. (1991). Metodologi penelitian Kualitatif. Bandung: Remaja Rosda Karya.

Rusli Luthan. 2001. Pengembangan Olahraga Masyarakat. Makalah Workshop Pengembangan Olahraga Masyarakat. Jakarta.

Soekanto, Soejono, 1999, Sosiologi Suatu Pengantar, Rajawali Press, Jakarta.

Strauss, A, and Corbin, J. (1990). Basics of Qualitative Research Grounded Theory Procedures and Techniques. London; Sage Publications.

Sutopo, HB. (2006). Penelitian Kualitatif: Dasar Teori dan Terapannya dalam Penelitian. Surakarta: Universitas Negeri Sebelas Maret

Suwarno. 2007. Perubahan sosial masyarakat Bakumpai di Tumbang Samba Kabupaten Katingan. Disertasi: Universitas Merdeka Malang. 